\title{
Current challenges and possible solutions to improve access to care and treatment for hepatitis C infection in Vietnam: a systematic review
}

\author{
Alessandra Berto ${ }^{1,2^{*}}$ D, Jeremy Day ${ }^{1,2}$, Nguyen Van Vinh Chau ${ }^{3}$, Guy E. Thwaites ${ }^{1,2}$, Ngoc Nghiem My ${ }^{1}$,
} Stephen Baker ${ }^{1,2,4}$ and Thomas C. Darton ${ }^{1,5}$

\begin{abstract}
Background: Hepatitis C infection is a major public health concern in low- and middle-income countries where an estimated 71.1 million individuals are living with chronic infection. The World Health Organization (WHO) has recently released new guidance for hepatitis $\mathrm{C}$ virus $(\mathrm{HCV})$ treatment programs, which include improving the access to new direct-acting antiviral agents. In Vietnam, a highly populated middle-income country, the seroprevalence of $\mathrm{HCV}$ infection is approximately $4 \%$ and multiple genotypes co-circulate in the general population. Here we review what is currently known regarding the epidemiology of HCV in Vietnam and outline options for reducing the significant burden of morbidity and mortality in our setting.

Methods: We performed a systematic review of the currently available literature to evaluate what has been achieved to date with efforts to control HCV infection in Vietnam.

Results: This search retrieved few publications specific to Vietnam indicating a significant gap in baseline epidemiological and public health data. Key knowledge gaps identified included an understanding of the prevalence in specific high-risk groups, characterization of circulating HCV genotypes in the population and likely response to treatment, and the extent to which HCV treatment is available, accessed and utilized.

Conclusions: We conclude that there is an urgent need to perform up to date assessments of HCV disease burden in Vietnam, especially in high-risk groups, in whom incidence is high and cross infection with multiple genotypes is likely to be frequent. Coordinating renewed surveillance measures with forthcoming HCV treatment studies should initiate the traction required to achieve the WHO goal of eliminating HCV as a public health threat by 2030, at least in this region.
\end{abstract}

Keywords: Hepatitis C virus, Treatment access, Low and middle-income countries, Epidemiology, Vietnam

\section{Background}

Approximately 71.1 million people worldwide have chronic hepatitis $C$ virus infection, resulting in over 500,000 deaths each year and creating a substantial burden on healthcare services [1-4]. The prevalence of hepatitis $C$ infection is estimated to be $1 \%$, although the highest burden (85\%) of

\footnotetext{
* Correspondence: aberto@oucru.org

'Oxford University Clinical Research Unit, Vietnam Wellcome Trust Major Overseas Programme, 764 Vo Van Kiet, District 5, Ho Chi Minh City, Vietnam ${ }^{2}$ Centre for Tropical Medicine and Global Health, Nuffield Department of Clinical Medicine, University of Oxford, Oxford, UK

Full list of author information is available at the end of the article
}

chronic infection is in low and middle income countries (LMICs) [1-4].

Hepatitis C virus $(\mathrm{HCV})$, a single-stranded positive RNA virus, can cause individual infection with multiple subtypes, and therefore knowledge of viral genotype is particularly important for predicting virological and clinical treatment response. Genotype distribution varies geographically and is known to be particularly diverse in Southeast Asia [1].

Recently, the treatment options available for chronic hepatitis $\mathrm{C}$ infection have undergone a revolution with 
development of the direct-acting antivirals (DAAs) [5]. Treatment regimes containing drugs from this new class have demonstrated significantly higher rates of sustained virological response (SVR) compared to standard interferon- (IFN) and ribavirin-focused regimes [6, 7]. Additional benefits of this class include shorter treatment durations, oral administration and fewer side-effects. It has been estimated that, with unrestricted access to these costly DAA-containing regimes, more than $90 \%$ of $\mathrm{HCV}$ infected patients could attain SVR and thus achieve a definitive cure [8].

In May 2016, the World Health Organisation (WHO) launched a new global strategy to eliminate viral hepatitis as public health threat by 2030 [9]. A key priority in these recommendations is to ensure open access to the DAAs [10]. However, individuals living in LMICs, are unlikely to be able to afford regimes containing these new costly treatments [10]. Ongoing efforts to ensure equity of access include the development of generic drug formulations [10, 11].

The Socialist Republic of Vietnam has a population exceeding 93 million people. Since the mid-1980s there have been dramatic improvements in the key development indicators of this Southeast Asian country, including increases in life expectancy, gross-domestic product and expanding state and private healthcare provision [12]. This includes a new national strategy to improve access to viral hepatitis diagnostic and treatment services [12]. To achieve the WHO stated goal of HCV elimination as a public health problem, understanding how the control of HCV in countries such as Vietnam could be improved, is vital. This article aims to review the currently available published literature regarding the epidemiology, virological features and the current treatment options available for hepatitis $\mathrm{C}$ infection in Vietnam. We use these data to propose measures which could help in reducing the burden of $\mathrm{HCV}$ infections in Vietnam.

\section{Methods}

\section{Search strategy and selection criteria}

We searched PubMed-, MEDLINE- and Embase-indexed articles for English-Vietnamese languages articles in June 2016, according to the PRISMA guidelines (Fig. 1) [13].

Databases were searched using a combination of the following $\mathrm{MeSH}$ terms and keywords, including (Hepatitis $C$ virus OR HCV) AND Vietnam AND (Prevalence OR Epidemiology OR Surve* OR Seroprevalence) (OR hepatitis C). No date restriction was used although included articles/data were restricted to original research articles relating to hepatitis $\mathrm{C}$ infection and $\mathrm{HCV}$ in Vietnam only, and on those published in either English or Vietnamese. We further searched the clinical trials registry http:/ClinicalTrial.gov for treatment trials

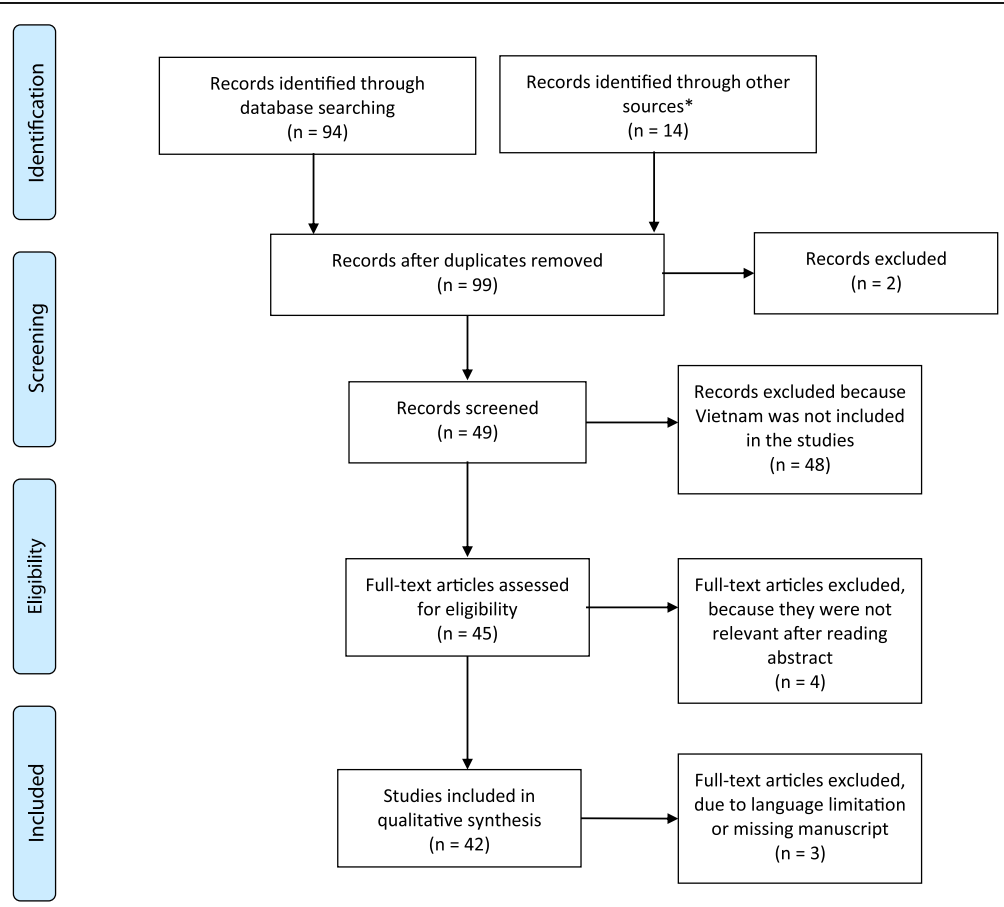

Fig. 1 Flow chart of studies included in data synthesis. * Other sources from which records were obtained include Clinicaltrials.gov ( $n=9$, see Table 2) and Standard Operating Procedures for the identification, diagnosis and management of Hepatitis C infection published in Vietnamese and identified through web searches $(n=5)$ 
currently underway or completed in Vietnam using the search term "Hepatitis C" AND "Vietnam".

After performing the literature searches, one author (AB) extracted and screened the titles and abstracts before selecting and reviewing the full-text articles. The following data were extracted from each article: first author's name, publication year, country of origin, date of study, type of patient group, and additional details of epidemiology, seroprevalence, $\mathrm{HCV}$ RNA positivity figures, treatment availability etc.

\section{Results}

\section{Search results}

A total of 99 abstracts for manuscripts published between September 1990 and June 2016 were identified. Of these, 42 contained information relevant for our review and full texts were retrieved [11, 14-60] (Table 1 and Fig. 1). The majority of publications $(73.8 \%, 31 / 42)$ assessed the prevalence of HCV infection specifically in high-risk groups, including HIV infected patients, injecting drug users (IDU), community sex workers (CSW), men that have sex with men (MSM) and renal haemodialysis patients $[11,17,21-23,25,26,28,29,31,32,34$, 36, 37, 39, 41-47, 51-53, 55-60] (Table 1). Online search for Vietnamese articles retrieved one research publication and four Standard Operating Procedures (SOPs); only the Vietnamese research paper retrieved from a Vietnamese journal was included in this analysis [38].

Twenty one percent (9/42) of the publications reported data from Ho Chi Minh City (HCMC) or from the southern Vietnam region (Table 1), while 52.3\% (22/ 42) reported studies conducted in the north of the country, principally in Hanoi and surrounding provinces $[18,22,27,32,36,47,49,52,53]$ (Table 1). Eight of forty two retrieved publications characterized the diversity of HCV genotypes in Vietnam [14, 16, 21, 33, 34, 48, 50, 51] (Table 1). Two manuscripts were reviews assessing risk factors associated with $\mathrm{HCV}$ acquisition in Vietnam $[11,24]$. One article, retrieved from a Vietnamese website assessed the prevalence of $\mathrm{HCV}$ in the Vietnamese ethnic minority [38].

Nine clinical trials were found registered with ClinicalTrials.com (see Table 2). Five out of nine were completed but no results have been published to-date, two are completed with results available, one is active but no recruiting, while one is actively recruiting (Fig. 1). Only the two clinical trials that had published results were included in the review, the remaining seven studies have been excluded.

\section{The epidemiology of hepatitis C in Vietnam}

In Vietnam, the background prevalence of $\mathrm{HCV}$ infection in the general population, at least historically, appears to vary depending on the region studied. In 1994 it was estimated that the seroprevalence in individuals without liver disease was $9 \%(43 / 491 ; 95 \% \mathrm{CI}$, $6.4 \%-11.5 \%)$ and $4 \%(18 / 511 ; 95 \% \mathrm{CI}, 2.3 \%-5.6 \%)$ in HCMC and Hanoi, respectively [53] (Fig. 2). By 1998 it was estimated that in $\mathrm{HCMC}$, the HCV seroprevalence in patients with underlying liver disease was $23 \%$ (69/ 289; $95 \% \mathrm{CI}, 18.1 \%-27.8 \%$ ) and in this population, $\mathrm{HCV}$ RNA was detectable in blood of $61 \%(42 / 69 ; 95 \%$ CI, $49.4 \%-72.5 \%)$ of the individuals [47]. This same study reported an HCV seroprevalence in healthy individuals in Da Lat (in the Southern Highlands) of 1\% (9/890; 95\% CI, $0.9 \%-1.0 \%)$; HCV RNA was detected in $44 \%(4 / 9)$ of these individuals [47]. Four years later in 2002, HCV RNA detection in HCMC was estimated to be $2 \%$ (2/ 100; $95 \% \mathrm{CI}, 1.3 \%-5.3 \%$ ) in apparently healthy individuals and 33\% (45/234; 95\% CI, 27.0\%-39.0\%) in patients with liver disease [15]. In Binh Thuan province $(212 \mathrm{~km}$ northeast of HCMC) HCV seroprevalence in the general population between 2005 and 2007 was estimated to be $3.3 \%$ (17/509; $95 \% \mathrm{CI}, 1.7 \%-4.8 \%)$; the male population exhibited a higher burden of seropositive samples (3.3\%) than women (1.8\%), and HCV RNA was detected in $52.9 \%(9 / 17)$ of the identified anti-HCV positive individuals (Fig. 2) [30]. Furthermore, one article was retrieved from a Vietnamese journal. The original manuscript was in Vietnamese and only the abstract was translated in English. The manuscript assessed the seroprevalence of $\mathrm{HCV}$ in the Vietnamese ethnic minority in the north of Vietnam and the detected seroprevalence in 1305 individuals was $1.22 \%$ (95\% CI, $0.6 \%-1.7 \%$ ) in 2011 [38].

The majority of the remaining publications evaluated HCV prevalence in specific high-risk groups (Table 1). These data estimated that $89 \%(1255 / 1434 ; 95 \% \mathrm{CI}$, $87.3 \%-90.6 \%$ ) of IDU in Nguyen province (Northern Vietnam) were HCV RNA positive between 2005 and 2007 and 35\% (502/1434; 95\% CI, 32.5\%-37.4) were $\mathrm{HIV} / \mathrm{HCV}$ co-infected [29]. Similar figures were reported in Hai Phong province (northern Vietnam) in 2014 (Fig. 2 ), where the prevalence of $\mathrm{HCV}$ in HIV-infected individual was $89.4 \%$ (93/104; 95\% CI, 82.1\%-96.6\%). This study also reported that the majority of HCV cases presented with clinical features of advanced liver fibrosis and cirrhosis [26].

Between 2005 and 2012, several studies were conducted around Vietnam (including HCMC, Hanoi, Hai Phong Province, Da Nang, Khanh Hoa Province and Can Tho), which aimed to determine HCV seroprevalence in patients undergoing renal haemodialysis or receiving multiple blood transfusions [23, 37]. These six hospital-based studies found an apparent iatrogenic HCV seroprevalence of $26 \%(n=153 / 575$; 95\% CI, 22.4\%-29.5\%) and was similar at all sites assessed. 
Table 1 Characteristics population-based studies reporting prevalence of HCV in Vietnam

\begin{tabular}{|c|c|c|c|c|c|}
\hline Year & First Author & Prevalence & Group Type & Sample Size & Reference \\
\hline 1998 & Kakumu & $1 \%$ & General Population & 1179 & {$[47]$} \\
\hline 2007 & Nguyen & $1 \%$ & General Population & 837 & {$[45]$} \\
\hline 2015 & Quesada & $4.7 \%$ & General Population & $27 / 571$ & {$[27]$} \\
\hline 2015 & Do & $\begin{array}{l}3.3 \% \\
1.3 \%{ }^{*}\end{array}$ & General population & 509 & [30] \\
\hline 2003 & Tran & $2 \%$ & General population & 334 & {$[15]$} \\
\hline 1996 & Corwin & $2 \%$ & General population & 188 & [49] \\
\hline 2012 & Sereno & $0.38-4.3 \%$ & General population & $N A^{b}$ & {$[21]$} \\
\hline 2016 & Martinello & $42.5 \%$ & HIV & $89.452^{\mathrm{a}}$ & [24] \\
\hline 2015 & Nadol & $53.3 \%$ & HIV/IDU & 3010 & [32] \\
\hline 2015 & Zang & $88 \%$ & HIV & 1434 & [29] \\
\hline 1999 & Follézou & $>80 \%$ & HIV & 280 & [18] \\
\hline 2012 & Durier & $22.9 \%$ & HIV & 110 & {$[20]$} \\
\hline 2016 & Nguyen & $89 \%$ & HIV & 104 & {$[26]$} \\
\hline 2016 & Hser & $74 \%$ & HIV/IDU & $N A^{b, c}$ & [11] \\
\hline 2012 & Sereno & $95.8 \%$ & HIV/IDU & $N A^{b}$ & {$[21]$} \\
\hline 2012 & Gish & $87 \%$ & IDU & $N A^{b}$ & [36] \\
\hline 1998 & Kakumu & $47 \%$ & Liver Disease & 1179 & {$[47]$} \\
\hline 2003 & Tran & $10 \%$ & Liver disease & 334 & {$[15]$} \\
\hline 1996 & Corwin & $10 \%$ & Liver Disease & 188 & [49] \\
\hline 2004 & Buchy & $9 \%$ & Liver disease & 45 & {$[46]$} \\
\hline 2012 & Gish & $23 \%$ & Liver disease & $N A^{b}$ & [36] \\
\hline 1993 & Cordier & $2 \%$ & Hepatocarcinoma & 152 & [54] \\
\hline 2010 & Bjoerkvoll & $12.7 \%$ & Blood donors & 1305 & {$[38]$} \\
\hline 2012 & Viet & $76.4 \%$ & Blood Donors & $1200^{\mathrm{a}}$ & [40] \\
\hline 1994 & Song & $20.6 \%$ & Blood Donors & 491 & {$[52]$} \\
\hline 2012 & Dunford & $26.6 \%$ & Dialysis & $8652^{\mathrm{a}}$ & [37] \\
\hline 2016 & Duong & $8 \%$ & Dialysis & 142 & {$[22]$} \\
\hline 2015 & Duong & $6 \%$ & Dialysis & 113 & {$[31]$} \\
\hline 2012 & Gish & $54 \%$ & Hemodialysis & $N A^{b}$ & {$[36]$} \\
\hline 2016 & Nadol & $28.4 \%$ & MSM & 1588 & {$[25]$} \\
\hline 2012 & Dunford & $8.7 \%$ & CSW & $8652^{\mathrm{a}}$ & {$[37]$} \\
\hline
\end{tabular}

*Presence of HCV RNA

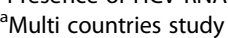

${ }^{\mathrm{b}} N A$ Not applicable

${ }^{\mathrm{c}}$ Estimate

In 2010, a study estimated the prevalence of $\mathrm{HCV}$ infection in MSM in the south of Vietnam (Can Tho and HCMC) and in the north of Vietnam (Hai Phong Province and Hanoi) [25]. The overall seroprevalence of infection in 1588 male participants was $28.4 \%$ (95\% CI, $26.1 \%-30.6 \%$ ) [25]; $29 \%$ of the individuals were coinfected with HIV and more northerly regions observed a higher $\mathrm{HCV}$ and $\mathrm{HCV} / \mathrm{HIV}$ co-infection prevalence [25]. A single publication from 1997 assessed the frequency of $\mathrm{HCV}$ infection in patients with chronic hepatitis in $\mathrm{HCMC}$, and concluded that $\mathrm{HCV}$ was the underlying etiology in $19-27 \%$ of chronic hepatitis cases [19]. However, no indication of the sample size used to derive this estimate was provided.

\section{The molecular epidemiology of HCV in Vietnam}

A study conducted in four major conurbations in Vietnam - Hanoi, Hai Phong Province, Da Nang, Khanh Hoa Province and Can Tho, identified HCV genotypes 1, 6,3 and 2 in 59.9\% $(n=169), 37.9 \%(n=107), 1.8 \%$ $(n=5)$ and $0.4 \%(n=1)$ of samples collected from mixed healthy and high-risk populations, respectively 
Table 2 List of the clinical trials conducted in Vietnam to date ${ }^{a}$

\begin{tabular}{|c|c|c|c|c|}
\hline Year & Title & City & Sponsor & Status \\
\hline $2010-2016$ & $\begin{array}{l}\text { Hepatic Safety of Raltegravir Versus Efavirenz as HIV Therapy for } \\
\text { Patients With HIV and HCV Coinfection }\end{array}$ & $\begin{array}{l}\text { Ho Chi Minh } \\
\text { City, Hai Phong }\end{array}$ & University of Hawaii & $\begin{array}{l}\text { Active, not } \\
\text { recruiting }\end{array}$ \\
\hline 2014-2016 & $\begin{array}{l}\text { The Study of Safety, Pharmacokinetics, Pharmacodynamics of } \\
\text { Peglamda (Peginterferon Lamda 1) on Healthy Volunteers and } \\
\text { the Preliminary Evaluation of Peglamda and Hepasig (Ribavirin) } \\
\text { Treatment's Effects on Chronic Hepatitis C Patients }\end{array}$ & Unknown & $\begin{array}{l}\text { Nanogen Pharmaceutical } \\
\text { Biotechnology Co., Ltd }\end{array}$ & Completed \\
\hline \multirow[t]{2}{*}{ 2015-2016 } & Feasibility of Interventions on People Who Inject Drugs in Vietnam & & & \\
\hline & $\begin{array}{l}\text { Implementation of a Sexual Health Intervention for Young Men } \\
\text { Who Have Sex With Men (MSM) in Two Vietnamese Cities }\end{array}$ & $\begin{array}{l}\text { Ho Chi Minh } \\
\text { City, Hanoi }\end{array}$ & Inserm-ANRS & Completed \\
\hline $2013-2016$ & HCV Treatment in HIV Co-Infected Patients in Asia & Hanoi & amfAR, & Completed \\
\hline 2016 & $\begin{array}{l}\text { Long Term Follow-up Study to Assess Durability of Sustained } \\
\text { Virologic Response in Alisporivir-treated Hepatitis C Patients }\end{array}$ & Unknown & Debiopharm International SA & $\begin{array}{l}\text { Completed, } \\
\text { has results }\end{array}$ \\
\hline $2011-2016$ & $\begin{array}{l}\text { Efficacy and Safety of Alisporivir Triple Therapy in Chronic } \\
\text { Hepatitis C Genotype } 1 \text { Treatment-naïve Participants }\end{array}$ & Unknown & Debiopharm International SA & $\begin{array}{l}\text { Completed, } \\
\text { has results }\end{array}$ \\
\hline 2016-2017 & $\begin{array}{l}\text { Efficacy and Safety of SofosbuvirNelpatasvir Fixed Dose } \\
\text { Combination for } 12 \text { Weeks in Participants With Chronic HCV }\end{array}$ & Unknown & Gilead Sciences & Recruiting \\
\hline 2015 & $\begin{array}{l}\text { 3-year Follow-up Study to Assess the Viral Activity in Hepatitis C } \\
\text { Patients Who Failed Feeder DEB025/Alisporivir Study }\end{array}$ & & Novartis Pharmaceuticals & Completed \\
\hline 2014-2016 & $\begin{array}{l}\text { Implementation of a Sexual Health Intervention for Young Men } \\
\text { Who Have Sex With Men (MSM) in Two Vietnamese Cities }\end{array}$ & Hanoi & $\begin{array}{l}\text { National Development and } \\
\text { Research Institutes, Inc. }\end{array}$ & Completed \\
\hline
\end{tabular}

${ }^{\mathrm{a}}$ For further details please see the following website: ClinicalTrials.gov

[37]. While genotype 1 was the most prevalent $\mathrm{HCV}$ genotype in all four areas, the genotype distribution ranged from $47 \%$ in Khanh Hoa Province to $81 \%$ in Da Nang [37]. These four genotypes $(1-3,6$, and) were identified in dialysis and multi-transfused individuals with nine recognized subtypes $(1 \mathrm{a}, 1 \mathrm{~b}, 2 \mathrm{a}, 3 \mathrm{a}, 3 \mathrm{~b}, 6 \mathrm{a}, 6 \mathrm{e}$, 6 h, 6 l) [39]. A further study similarly identified HCV genotype 1 as the predominant virus circulating in MSM in Hanoi, Hai Phong Province, HCMC and Can Tho [25]. Additionally, plasma samples from $97 \mathrm{HCV}$ infected individuals were molecularly characterized between 2003 and 2010 in HCMC. The RNA sequences obtained from these samples suggested that genotypes $1 \mathrm{~b}$ and 2a were imported from East Asia, 1a from the United States, $2 \mathrm{i}, 2 \mathrm{j}$ and $2 \mathrm{~m}$ imported from France $[33,58]$. They also identified an additional 4 subtypes of genotype 6 (6a, $6 \mathrm{ax}, 6 \mathrm{xb}$ and $6 \mathrm{xc}$ ) with no obvious international link [34].

\section{Clinical trials}

Of the nine trials registered on ClinicalTrials.gov, only two had published results available at time of review $[61,62]$. Both studies were sponsored by Debiopharm International SA and neither the source country information nor the locations where trial participant recruitment was performed within the country have been specified. Both studies were multicenter international trials to assess the treatment responses (SVR to single agent or combination treatment) to the synthetic cyclosporinelike agent, Alisporivir, a novel host-targeting antiviral (HTA) agent [61, 62].

\section{Discussion}

Our literature search identified a paucity of published data regarding the nature or burden of $\mathrm{HCV}$ infection in Vietnam. Studies in the publications identified were generally conducted in high-risk populations and focused in the more populous northern provinces (around Hanoi) and southern provinces (around HCMC) of the country. In addition, most studies have measured $\mathrm{HCV}$ antibody seroprevalence rather than HCV RNA prevalence, which would more reliably indicate the numbers of individuals with active infection. As elsewhere, the available literature suggested that blood transfusions, intravenous drug use, and unsafe therapeutic injections were a likely common source of $\mathrm{HCV}$ infection in the Vietnamese populations studied. Furthermore, the data suggests while the HCV seroprevalence in the general population is approximately $4 \%(18 / 511 ; 95 \%$ CI, 2.3\%-5.6\%) in Hanoi and 9\% (43/ 491; 95\% CI, 6.4\%-11.5\%) in Ho Chi Minh City, which is high in comparison to America or Europe [63, 64], this is likely to be even higher in IDU $(55.6 \%, n=556 /$ 1000; 95\% CI, 52.8\%-58.3\%), MSM (38.8\%; $n=1558$; 95\% CI, 36.3\%-41.2\%), and hemodialysis patients (26.6\%, $n=153 / 575 ;$; 95\% CI, $22.4 \%-29.5 \%$ ) [23, 31, 53, 57] . There are still substantial gaps in our understanding of the molecular epidemiology of HCV infection in Vietnam, however the limited findings from the few studies that have been conducted suggest that multiple $(\geq 4)$ $\mathrm{HCV}$ genotypes and subtypes are circulating in the population $[25,37]$. 

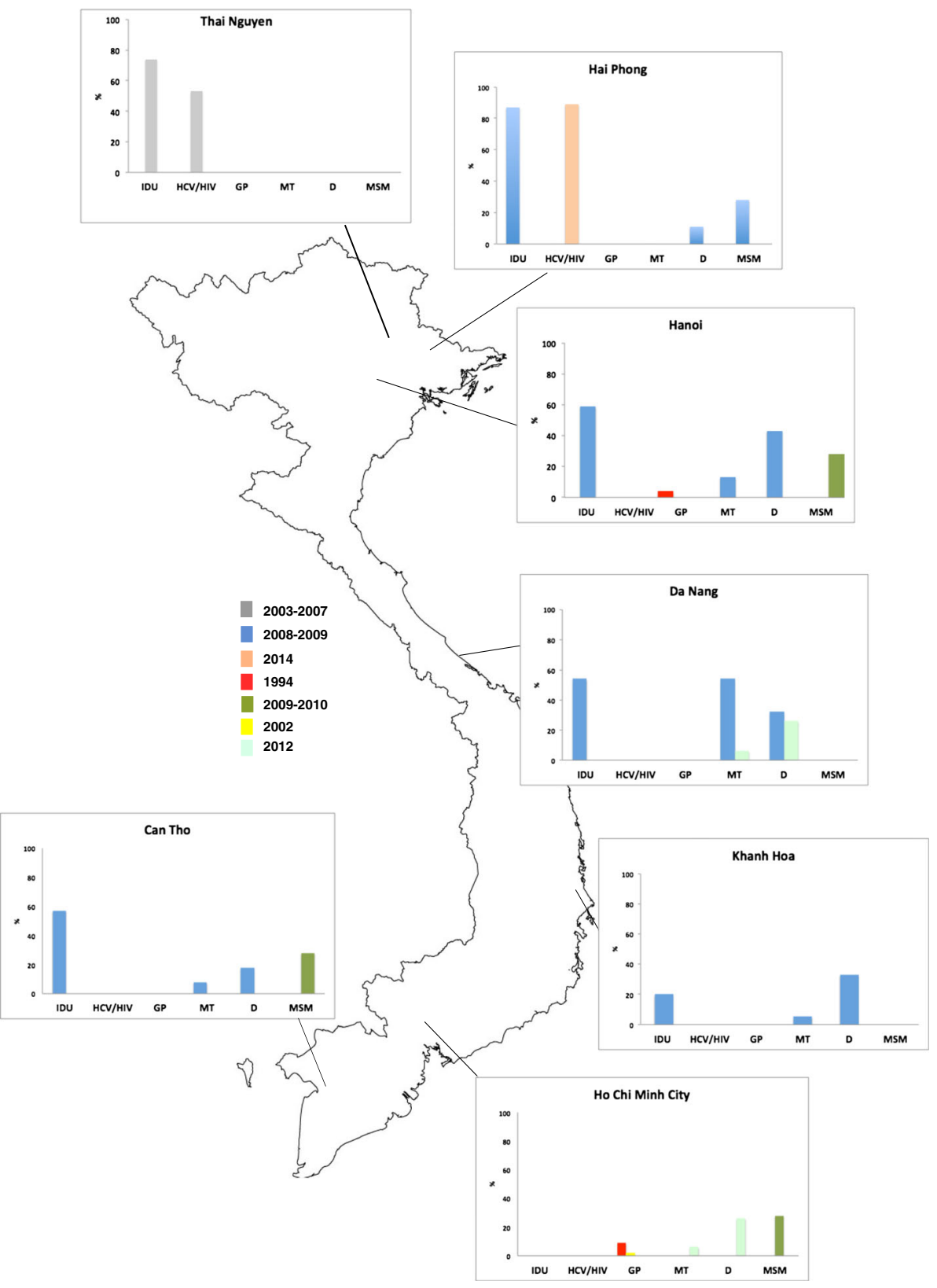

Fig. 2 Vietnam Map and summary of the main studies conducted so farA summary of the main studies performed in Vietnam to-date measuring the prevalence of HCV viral detection (PCR positivity) in selected populations by year of study publication and geographic location. ${ }^{*}$ Data for 'General adult healthy populations' is for measured anti-HCV antibody seroprevalence. The map represents the location where the main studies have been conducted and summarized the HCV prevalence or seroprevalence observed during the studies in different groups, such as IDU, MSM, liver disease, hemodialysis and multi-blood transfusion and general population

Ascertaining the burden of hepatitis $\mathrm{C}$ in Vietnam Ascertaining the true likely burden of infection in Vietnam would facilitate advocacy for the implementation of disease specific strategies and guidelines, and provide useful baseline data for further epidemiological measurements. Our search identified that HCV seroprevalence in the population may be high $(1-4 \%)$ compared to other countries in the region $[3,27,53]$. For example, several large-scale seroprevalence studies have reported HCV estimates of asymptomatic Chinese ranging from 0.39 to $3.2 \%$ depending of the region [65]. Other Asian countries such as Japan, India or Indonesia reported an $\mathrm{HCV}$ seroprevalence of between 2.3, 0.9 and 2.1\% respectively [4]. 
Observations supporting the speculation that the true seroprevalence might be underestimated include data from neighboring countries such as China, where the reported rate of $\mathrm{HCV}$ infections increased more than 10 -fold (from 21,000 reported cases/year to 210,000 reported cases/year) between 2003 and 2011 [66]. Reasons for this increase may include an increase in life expectancy and/or the increased detection/occurrence of new infections due to better surveillance and improved diagnostics. The ageing of the population creates two potentially major pressures on health care finances: increased utilization of health services and decreased revenues (as a declining share of the population is economically active).

Further insights into the current $\mathrm{HCV}$ situation in Vietnam may be provided by two non-resident populations; data on $\mathrm{HCV}$ infection in USA veterans after the Vietnam/American war suggest that returning veterans had a higher risk (10-17\%) of being HCV infected than the general North American population (1.3\%) [63, 64, 67]. This conflict was associated with the highest rate of $\mathrm{HCV}$ acquisition in comparison to any that the US has been engaged in. More recently, it was observed that Vietnamese migrants to other countries have a higher prevalence (5.8\%) of $\mathrm{HCV}$ infection when compared to the autochthonous population $(1.3 \%)[60,68]$.

The transmission of HCV infection in clinical settings is still particularly concerning in Vietnamese healthcare facilities; the high $\mathrm{HCV}$ prevalence $(26 \%)$ in haemodialysis patients $[23,31,57]$ has not been observed in other Asian-Pacific countries (0.7-18.1\%) [69]. This literature review also found a high seroprevalence $(27 \%)$ in other high-risk populations including IDU, MSM, and CSW, similar data has been reported from studies conducted between the Myanmar and Chinese border region [70].

We therefore speculate that the seroprevalence in the general population might be higher than that currently estimated as the limited data currently available (only 42 publications published in over two decades) is from studies performed in only a few locations across Vietnam and which mostly had relatively small sample sizes upon which to base these calculations. Of note, the two most recent and larger studies performed to estimate seroprevalence in the general population have found an HCV prevalence of 3.3 and 4.7\%, respectively [27, 30].

\section{Identifying the genetic characteristics of HCV to improve public health}

In addition to assessing the burden of $\mathrm{HCV}$ disease, further data is required regarding $\mathrm{HCV}$ genotype, viral mutations and viral loads in $\mathrm{HCV}$ infected patients in order to assess how to implement the recent HCV treatment guidance, and to estimate the cost-benefit of an integrated $\mathrm{HCV}$ control program.
While currently available data are limited, they imply a broad genetic diversity within circulating $\mathrm{HCV}$ strains in all parts of the country [33, 34, 37, 39, 58]. More detailed phylogenetic approaches have proposed that the $\mathrm{HCV}$ population has been influenced by the international turmoil of the past, with importation of genotypes that are more typically associated with North America, Europe and other parts of Asia [34]. This genetic variation can also be observed in high-risk groups, meaning that the formation of a local treatment policy may be more complex than in other locations. For example, the distribution of HCV genotype in haemodialysis patients is variable according to the geographical region, this may be due to a lack of infection control and or point source outbreaks [37]. This genotype distribution is in contrast to other countries in Asia, such as China, where hemodialysis patients are predominantly affected by genotype $2 \mathrm{HCV}[71,72]$. An improved understanding of the genotype distribution and frequency of viral treatment mutations among Vietnamese patients will facilitate the development of appropriate local guidelines.

\section{Current treatment options, molecular challenges and social taboos}

Early diagnosis and access to treatment are essential components for an effective $\mathrm{HCV}$ control program in Vietnam. As in most LMICs, current treatment for HCV infection in Vietnam is limited to interferon-based (IFNgamma and pegylated-IFN) therapy [10]. More recently, some patients have been treated with newer DAA agents at the Hospital for Tropical Diseases (HTD) in HCMC, where more than 18,000 patients with viral hepatitis are assessed each year. Further clinical treatment studies have received funding and are planned to commence in the near future [73].

The more widespread introduction of the DAAs is hindered by a lack of data regarding HCV genotype distribution and viral treatment mutations [74]. This lack of data is especially problematic for the early detection of treatment resistance mutations, which occurred previously with hepatitis B treatment and HCV treatment in Japan and North America [75-77]. Furthermore, the efficacy of DAAs against some of the less common genotypes, such as genotype 6 which was frequently identified in previously studies, is not well established [78].

Other barriers to increasing the utilization of $\mathrm{HCV}$ treatment in resource-limited settings such as Vietnam include high costs, a perceived complexity in treatment regimes and bureaucratic support for importation, licensing and distribution of medicines for which specific clinical trial data in the local populations is lacking. Vietnam is a rapidly developing country, whose GDP per-capita has increased from \$1095 to \$1684 from 2004 until 2014 [79]. However, the per capita income remains 
low ( \$1024) [80] with limited annual spending on healthcare (according to WHO, approximately \$264 in 2006) [80]. A large proportion of people in Vietnam do not invest in health insurance and even those who do may not have full coverage to expensive treatment courses: pegylated-interferon courses are reimbursed at $30 \%(\$ 10,000-18,000$ for a 48 week treatmentcourse), and this partial reimbursement is based on doctor opinion only, with no allowance given for those in high-risk populations such as haemodialysis patients [81, 82].

While the treatment of $\mathrm{HCV}$ infection requires prescription from a medical practitioner, a further concern is the non-completion of treatment courses due to high costs and changes in family/patient financial circumstances. Some patients may also travel to other countries in the region where medications, which may be substandard, might be more affordable. Incomplete or inadequate treatment courses are likely to lead to increased rates of viral resistance, which has been previously widely observed in hepatitis B treatment programs in Vietnam [83, 84]. Further, PEG + INF + RBV remains (as 2016) the first line of therapy for chronic patients in many part of Asia, Vietnam included [85].

\section{Study limitations}

The majority of the studies included here had small sample sizes and concentrated on groups of individuals at known high-risk of acquiring $\mathrm{HCV}$ infection thus risking an overestimation bias. Given the heterogeneity of the study populations sampled, in addition to the broad time period and diverse geographic locations described, more accurate meta-analysis is not currently feasible. Thus, a considerable knowledge gap remains regarding the likely true burden of chronic $\mathrm{HCV}$ infection in the general, healthy adult Vietnamese population.

\section{Conclusions}

Relatively little is known regarding the burden of $\mathrm{HCV}$ infection in the general population in Vietnam. Available data suggest that the seroprevalence could be higher than previously assumed, especially in known high-risk groups such as patients undergoing haemodialysis. Limited data predict a broad distribution of HCV genotypes and, to-date, very few HCV treatment trials have been performed in Vietnam. While HCV control programs in Vietnam are in their infancy, there is an urgent need for more detailed disease burden and viral genotyping data, which, in addition to planned treatment studies, could be used to inform the development of local HCV treatment strategies and thus eventual attainment of the 2030 elimination target.

\section{Abbreviations}

HCV: Hepatitis C virus; DAA: Direct acting anti-viral; HTD: Hospital for Tropical Diseases; HCMC: Ho Chi Minh City; IFN: Interferon-based; LMIC: Low to middle income countries; WHO: World Health organization; IDU: Injecting drug users; MSM: Men that have sex with men; CSW: Commercial sex workers; SVR: Sustained virological response

\section{Funding}

No funding was used for this manuscript.

\section{Availability of data and materials}

All data generated or analysed during this study are included in this published article [and its supplementary information files].

\section{Authors' contributions}

$A B$ performed the literature search and wrote the draft manuscript. TD made substantial contributions to conception and design; JD, SB and GET contributed with study revision and gave final approval. NG helped to retrieve data from HTD hospital. All authors contributed to this paper with revision editing, and final approval.

\section{Competing interests}

The authors declare that they have no competing interests.

\section{Consent for publication}

"Not applicable".

\section{Ethics approval and consent to participate}

This manuscript reports previously published data about HCV in Vietnam, no clinical studies were performed, therefore there was no need for ethics approval.

\section{Publisher's note}

Springer Nature remains neutral with regard to jurisdictional claims in published maps and institutional affiliations.

\section{Author details \\ ${ }^{1}$ Oxford University Clinical Research Unit, Vietnam Wellcome Trust Major Overseas Programme, 764 Vo Van Kiet, District 5, Ho Chi Minh City, Vietnam. ${ }^{2}$ Centre for Tropical Medicine and Global Health, Nuffield Department of Clinical Medicine, University of Oxford, Oxford, UK. ${ }^{3}$ Hospital for Tropical Diseases, Ho Chi Minh City, Vietnam. ${ }^{4}$ The London School of Hygiene and Tropical Medicine, London, UK. ${ }^{5}$ Department of Infection, Immunity and Cardiovascular Disease, University of Sheffield, Sheffield, UK.}

Received: 15 November 2016 Accepted: 29 March 2017 Published online: 11 April 2017

References

1. Gower E, Estes C, Blach S, Razavi-Shearer K, Razavi H. Global epidemiology and genotype distribution of the hepatitis C virus infection. J Hepatol. 2014; 61(1 Suppl):S45-57.

2. Simmonds P. Genetic diversity and evolution of hepatitis $C$ virus -15 years on. J Gen Virol. 2004;85(Pt 11):3173-88.

3. Blach S, Zeuzem S, Manns M, Altraif I, Duberg A-S, Muljono DH, et al. Global prevalence and genotype distribution of hepatitis $C$ virus infection in 2015: a modelling study. Lancet Gastroenterol Hepatol. 2016;2(3):161-76.

4. Shepard CW, Finelli L, Alter MJ. Global epidemiology of hepatitis C virus infection. Lancet Infect Dis. 2005;5(9):558-67.

5. Poordad F, Dieterich D. Treating hepatitis C: current standard of care and emerging direct-acting antiviral agents. J Viral Hepat. 2012;19(7):449-64.

6. Jacobson IM, McHutchison JG, Dusheiko G, Di Bisceglie AM, Reddy KR, Bzowej $\mathrm{NH}$, et al. Telaprevir for previously untreated chronic hepatitis C virus infection. N Engl J Med. 2011;364(25):2405-16.

7. Poordad F, McCone JJ, Bacon BR, Bruno S, Manns MP, Sulkowski MS, et al. Boceprevir for untreated chronic HCV genotype 1 infection. N Engl J Med. 2011;364(13):1195-206.

8. Hezode C, Bronowicki JP. Ideal oral combinations to eradicate HCV: the role of ribavirin. J Hepatol. 2016;64(1):215-25.

9. WHO. Combating hepatitis $B$ and $C$ to reach elimination by 2030 . World Health Organisation; 2016. 
10. World Health Organization. Guidelines for the screening, care and treatment of persons with hepatitis C infection; 2016. p. 1-135.

11. Hser Y-I, Liang D, Lan Y-C, Vicknasingam BK, Chakrabarti A. Drug abuse, HIV, and HCV in Asian countries. J Neurolmmune Pharmacol. 2016;11:383.

12. Ministry of Health. Plan of preventing viral Hepatits Deseases in Vietnam 2015-2019. 2015.

13. Moher D, Liberati A, Tetzlaff J, Altman DG. Preferred reporting items for systematic reviews and meta-analyses: the PRISMA statement. PLoS Med. 2009;6(7):e1000097.

14. Nakano T, Lu L, Liu P, Pybus OG. Viral gene sequences reveal the variable history of hepatitis C virus infection among countries. J Infect Dis. 2004; 190(6):1098-108.

15. Tran HT-T, Ushijima H, Quang VX, Phuong N, Li TC, Hayashi S, et al. Prevalence of hepatitis virus types $B$ through $E$ and genotypic distribution of HBV and HCV in ho chi Minh City. Vietnam Hepatol Res. 2003;26(4):275-80.

16. Tran HT-T, Ushijima H, Ngoc TT, Ha LD, Hayashi S, Sata T, et al. Recombination of genotypes B and C in hepatitis B virus isolated from a Vietnamese patient with fulminant hepatitis. Jpn J Infect Dis. 2003;56(1):35-7.

17. Nerurkar VR, Woodward CL, Nguyen HT, DeWolfe MF, Tashima LT, ZallesGanley A, et al. Lack of association between acquisition of $\Pi$ virus and risk behavior for HIV and HCV infection in Vietnam. Int J Infect Dis. 1999:3(4):181-5.

18. Follezou JY, Lan NY, Lien TX, Lafon ME, Tram LT, Hung PV, et al. Clinical and biological characteristics of human immunodeficiency virus-infected and uninfected intravascular drug users in ho chi Minh City, Vietnam. AmJTrop Med Hyg. 1999;61(3):420-4

19. Ha MV. Some peculiarities of hepatobiliary diseases in Vietnam. J Gastroenterol Hepatol. 1997;12(5):S15-8.

20. Durier N, Nguyen C, White LJ. Treatment of hepatitis C as prevention: a modeling case study in Vietnam. PLoS One. 2012;7(4):e34548.

21. Sereno L, Mesquita F, Kato M, Jacka D, Van Nguyen TT, Nguyen TN. Epidemiology, responses, and way forward: the silent epidemic of viral hepatitis and HIV coinfection in Vietnam. J Int Assoc Physicians AIDS Care (Chic). 2012;11(5):311-20

22. Duong CM, Olszyna DP, Nguyen PD, ML ML. Challenges of hemodialysis in Vietnam: experience from the first standardized district dialysis unit in ho chi Minh City. BMC Nephrol. 2015;16:122.

23. Duong CM, McLaws M-L. An investigation of an outbreak of hepatitis C virus infections in a low-resourced hemodialysis unit in Vietnam. Am J Infect Control. 2016;44(5):560-6.

24. Martinello M, Amin J, Matthews GV, Dore GJ. Prevalence and disease burden of HCV Coinfection in HIV cohorts in the Asia Pacific region: a systematic review and meta-analysis. AIDS Rev. 2016;18(2):68-80.

25. Nadol P, O'Connor S, Duong H, Mixson-Hayden T, Tram TH, Xia G-L, et al. High hepatitis $C$ virus (HCV) prevalence among men who have sex with men (MSM) in Vietnam and associated risk factors: 2010 Vietnam Integrated Behavioural and Biologic Cross-Sectional Survey. Sex Transm Infect. 2016.

26. Nguyen Truong T, Laureillard D, Lacombe K, Duong Thi H, Pham Thi Hanh P, Truong Thi Xuan L, et al. High proportion of HIV-HCV Coinfected patients with advanced liver fibrosis requiring hepatitis $C$ treatment in Haiphong, northern Vietnam (ANRS 12262). PLoS One. 2016;11(5):e0153744.

27. Quesada P, Whitby D, Benavente Y, Miley W, Labo N, Chichareon S, et al. Hepatitis $C$ virus seroprevalence in the general female population from 8 countries. J Clin Virol. 2015;68:89-93.

28. Wasitthankasem R, Vongpunsawad S, Siripon N, Suya C, Chulothok P, Chaiear K, et al. Genotypic distribution of hepatitis $C$ virus in Thailand and Southeast Asia. PLoS One. 2015;10(5):e0126764.

29. Zhang L, Celentano DD, Le Minh N, Latkin CA, Mehta SH, Frangakis C, et al. Prevalence and correlates of HCV monoinfection and HIV and HCV coinfection among persons who inject drugs in Vietnam. Eur J Gastroenterol Hepatol. 2015;27(5):550-6.

30. Do SH, Yamada H, Fujimoto M, Ohisa M, Matsuo J, Akita T, et al. High prevalences of hepatitis $B$ and $C$ virus infections among adults living in Binh Thuan province, Vietnam. Hepatol Res. 2015;45(3):259-68.

31. Duong CM, Olszyna DP, ML ML. Hepatitis B and C virus infections among patients with end stage renal disease in a low-resourced hemodialysis center in Vietnam: a cross-sectional study. BMC Public Health. 2015:15:192.

32. Nadol P, O'connor S, Duong H, Le L-VN, Thang PH, Tram TH, et al. Findings from integrated behavioral and biologic survey among males who inject drugs (MWID) - Vietnam, 2009-2010: evidence of the need for an integrated response to HIV, hepatitis B virus, and hepatitis C virus. PLoS One. 2015; 10(2):e0118304.
33. Li C, Yuan M, Lu L, Lu T, Xia W, Pham VH, et al. The genetic diversity and evolutionary history of hepatitis C virus in Vietnam. Virology. 2014;468-470:197-206.

34. Li C, Pham VH, Abe K, Lu L. Nine additional complete genome sequences of HCV genotype 6 from Vietnam including new subtypes 6xb and 6xc. Virology. 2014;468-470:172-7.

35. Viet L, Lan NTN, Ty PX, Bjorkvoll B, Hoel H, Gutteberg T, et al. Prevalence of hepatitis B \& hepatitis $C$ virus infections in potential blood donors in rural Vietnam. Indian J Med Res. 2012;136(1):74-81.

36. Gish RG, Bui TD, Nguyen CTK, Nguyen DT, Tran HV, Tran DMT, et al. Liver disease in Viet Nam: screening, surveillance, management and education: a 5-year plan and call to action. J Gastroenterol Hepatol. 2012;27(2):238-47.

37. Dunford L, Carr MJ, Dean J, Waters A, Nguyen LT, Ta Thi TH, et al. Hepatitis $C$ virus in vietnam: high prevalence of infection in dialysis and multitransfused patients involving diverse and novel virus variants. PLOS One. 2012;7(8):1-10.

38. Nguyễn ThịLan Anh, Dương ThịThu Thủy, Nguyễn Thùy Linh Bùi ThịLan Anh, Nguyễn Tuấn Nghĩa NTH. Tình trạng nhiễm vi rút viêm gan $B$ và Cởcộng đồng dân tộc thiểu sốxã MỏVàng, huyện Văn Yên, tỉnh Yên Bái. Vietnamese J Prev Med. 2013:49(147):1.

39. Pham VH, Nguyen HDP, Ho PT, Banh DV, Pham HLT, Pham PH, et al. Very high prevalence of hepatitis $C$ virus genotype 6 variants in southern Vietnam: large-scale survey based on sequence determination. Jpn J Infect Dis. 2011;64(6):537-9.

40. Bjoerkvoll B, Viet L, Ol HS, Lan NTN, Sothy S, Hoel H, et al. Screening test accuracy among potential blood donors of $\mathrm{HBsAg}$, anti-HBC and anti-HCV to detect hepatitis B and C virus infection in rural Cambodia and Vietnam. Southeast Asian J Trop Med Public Health. 2010;41(5):1127-35.

41. Tanimoto T, Nguyen HC, Ishizaki A, Chung PTT, Hoang TTH, Nguyen VT, et al. Multiple routes of hepatitis $C$ virus transmission among injection drug users in Hai Phong, northern Vietnam. J Med Virol. 2010;82(8):1355-63.

42. Clatts MC, Colon-Lopez V, Giang LM, Goldsamt LA. Prevalence and incidence of HCV infection among Vietnam heroin users with recent onset of injection. J Urban Health. 2010;87(2):278-91.

43. Pham DA, Leuangwutiwong P, Jittmittraphap A, Luplertlop N, Bach HK, Akkarathamrongsin S, et al. High prevalence of hepatitis $C$ virus genotype 6 in Vietnam. Asian Pac J Allergy Immunol. 2009;27(2-3):153-60.

44. Quan VM, Go VF, Nam L Van, Bergenstrom A, Thuoc NP, Zenilman J, et al. Risks for HIV, HBV, and HCV infections among male injection drug users in northern Vietnam: a case-control study. AIDS Care; 2009;21(1):7-16.

45. Nguyen VTT, McLaws M-L, Dore GJ. Prevalence and risk factors for hepatitis C infection in rural north Vietnam. Hepatol Int. 2007;1(3):387-93.

46. Buchy P, Monchy D, An TTN, Srey CT, Tri DV, Son S, et al. Prevalence of hepatitis a, B, C and E virus markers among patients with elevated levels of Alanine aminotransferase and Aspartate aminotransferase in Phnom Penh (Cambodia) and Nha Trang (Central Vietnam). Bull Soc Pathol Exot. 2004; 97(3):165-71. Article in Russian

47. Kakumu S, Sato K, Morishita T, Trinh KA, Nguyen HB, Banh VD, et al. Prevalence of hepatitis $B$, hepatitis $C$, and $G B$ virus $C$ /hepatitis $G$ virus infections in liver disease patients and inhabitants in ho chi Minh, Vietnam. J Med Virol. 1998;54(4):243-8.

48. Simmonds P, Mellor J, Sakuldamrongpanich T, Nuchaprayoon C, Tanprasert $S$, Holmes EC, et al. Evolutionary analysis of variants of hepatitis $C$ virus found in South-East Asia: comparison with classifications based upon sequence similarity. J Gen Virol. 1996 Dec;77(Pt 12):3013-24

49. Corwin AL, Dai TC, Duc DD, Suu PI, Van NT, Ha LD, et al. Acute viral hepatitis in Hanoi, Viet Nam. Trans R Soc Trop Med Hyg. 1996;90(6):647-8.

50. Mellor J, Walsh EA, Prescott LE, Jarvis LM, Davidson F, Yap PL, et al. Survey of type 6 group variants of hepatitis C virus in Southeast Asia by using a core-based genotyping assay. J Clin Microbiol. 1996;34(2):417-23.

51. Tokita H, Okamoto H, Tsuda F, Song P, Nakata S, Chosa T, et al. Hepatitis C virus variants from Vietnam are classifiable into the seventh, eighth, and ninth major genetic groups. Proc Natl Acad Sci U S A. 1994;91(23):11022-6.

52. Song P, Duc DD, Hien B, Nakata S, Chosa T, Watanabe J, et al. Markers of hepatitis $C$ and $B$ virus infections among blood donors in ho chi Minh City and Hanoi, Vietnam. Clin Diagn Lab Immunol. 1994;1(4):413-8.

53. Nakata $S$, Song $P$, Duc DD, Nguyen XQ, Murata $K$, Tsuda F, et al. Hepatitis C and $B$ virus infections in populations at low or high risk in ho chi Minh and Hanoi, Vietnam. J Gastroenterol Hepatol. 1994:9(4):416-9.

54. Cordier S, Le TB, Verger P, Bard D, Le CD, Larouze B, et al. Viral infections and chemical exposures as risk factors for hepatocellular carcinoma in Vietnam. Int J Cancer. 1993;55(2):196-201. 
55. Toan NL, Song LH, Kremsner PG, Duy DN, Binh VQ, Koeberlein B, et al. Impact of the hepatitis $B$ virus genotype and genotype mixtures on the course of liver disease in Vietnam. Hepatology. 2006;43(6):1375-84.

56. Phung TBT, Alestig E, Nguyen TL, Hannoun C, Lindh M. Genotype X/C recombinant (putative genotype I) of hepatitis B virus is rare in Hanoi, Vietnam-genotypes B4 and C1 predominate. J Med Virol. 2010:82(8):1327-33.

57. Dunford L, Carr MJ, Dean J, Waters A, Nguyen LT, Ta Thi TH, et al. Hepatitis $C$ virus in Vietnam: high prevalence of infection in dialysis and multitransfused patients involving diverse and novel virus variants. PLoS One. 2012;7(8):e41266.

58. Fu Y, Qin W, Cao H, Xu R, Tan Y, Lu T, et al. HCV 6a prevalence in Guangdong province had the origin from Vietnam and recent dissemination to other regions of China: phylogeographic analyses. PLoS One. 2012;7(1):e28006.

59. Sy BT, Nguyen HM, Toan NL, Song LH, Tong HV, Wolboldt C, et al. Identification of a natural intergenotypic recombinant hepatitis delta virus genotype 1 and 2 in Vietnamese HBsAg-positive patients. J Viral Hepat. 2015;22(1):55-63.

60. Caruana S, Bowden S, Kelly H. Transmission of HCV in the Vietnamese community. Aust N Z J Public Health. 2001;25:276.

61. ClinicalTrails.gov. No Title. Efficacy and Safety of Alisporivir Triple Therapy in Chronic Hepatitis C Genotype 1 Treatment-naïve Participants. 2016.

62. ClinicalTrials.gov. No Title. Long Term Follow-up Study to Assess Durability of Sustained Virologic Response in Alisporivir-treated Hepatitis C Patients. 2016.

63. Zuniga IA, Chen JJ, Lane DS, Allmer J, Jimenez-Lucho VE. Analysis of a hepatitis C screening programme for US veterans. Epidemiol Infect. 2006; 134(2):249-57.

64. Roselle GA, Danko LH, Kralovic SM, Simbartl LA, Kizer KW. National Hepatitis C Surveillance day in the veterans health Administration of the Department of veterans affairs. Mil Med. 2002;167(9):756-9.

65. Qin Q, Smith MK, Wang L, Su Y, Wang L, Guo W, et al. Hepatitis C virus infection in China: an emerging public health issue. J Viral Hepat. 2015;22(3): 238-44

66. Duan Z, Jia J-D, Hou J, Lou L, Tobias H, Xu XY, et al. Current challenges and the management of chronic hepatitis $C$ in mainland China. J Clin Gastroenterol. 2014:48(8):679-86.

67. Brau N, Bini EJ, Shahidi A, Aytaman A, Xiao P, Stancic S, et al. Prevalence of hepatitis $C$ and coinfection with HIV among United States veterans in the new York City metropolitan area. Am J Gastroenterol. 2002;97(8):2071-8.

68. Richter C, Ter Beest G, Gisolf EH, VAN Bentum P, Waegemaekers C, Swanink $C$, et al. Screening for chronic hepatitis $B$ and $C$ in migrants from Afghanistan, Iran, Iraq, the former soviet republics, and Vietnam in the Arnhem region, The Netherlands. Epidemiol Infect. 2014;142(10):2140-6.

69. Johnson DW, Dent H, Yao Q, Tranaeus A, Huang C-C, Han D-S, et al. Frequencies of hepatitis $B$ and $C$ infections among haemodialysis and peritoneal dialysis patients in Asia-Pacific countries: analysis of registry data. Nephrol Dial Transplant. 2009;24(5):1598-603.

70. Li L, Assanangkornchai S, Duo L, McNeil E, Li J. Risk behaviors, prevalence of HIV and hepatitis $C$ virus infection and population size of current injection drug users in a China-Myanmar border city: results from a respondentdriven sampling survey in 2012. PLoS One. 2014;9(9):e106899.

71. Khan S, Attaullah S, Ali I, Ayaz S, Naseemullah, Khan SN, et al. Rising burden of hepatitis C virus in hemodialysis patients. Virol J. 2011:8:438.

72. Pybus OG, Barnes E, Taggart R, Lemey P, Markov PV, Rasachak B, et al. Genetic history of hepatitis C virus in East Asia. J Virol. 2009;83(2):1071-82.

73. DNDI. An alternative reseach and development strategy to deliver afforadble treatments for hepatitis C patients. The Drugs for Neglected Diseases initiative's 2016.

74. Pawlotsky J, REVIEWS IN. BASIC AND CLINICAL GASTROENTEROLOGY AND HEPATOLOGY in Interferon-Free Regimens. Gastroenterology. 2016;151(1): 70-86.

75. Gu L, Han Y, Li Y, Zhu T, Song X, Huang Y, et al. Emergence of LamivudineResistant HBV during antiretroviral therapy including Lamivudine for patients Coinfected with HIV and HBV in China. PLoS One. 2015;10(8): e0134539.

76. Cento V, Chevaliez S, Perno CF. Resistance to direct-acting antiviral agents: clinical utility and significance. Curr Opin HIV AIDS. 2015;10(5):381-9.

77. Chayama K, Hayes CN. HCV drug resistance challenges in Japan: the role of pre-existing variants and emerging Resistant strains in direct acting antiviral therapy. Viruses. 2015;7(10):5328-42.
78. Antaki N, Craxi A, Kamal S, Moucari R, Van der Merwe S, Haffar S, et al. The neglected hepatitis $C$ virus genotypes 4, 5 and 6: an international consensus report. Liver Int. 2010;30(3):342-55.

79. WBG. The Word bank Country Srurvey FY14. Word Bank Group; 2014.

80. Res JMB, SP S, Shyamala R, JR R, RRM V, Dwivedi M, et al. Global policy report on the prevention and control of viral hepatitis IN WHO MEMBER STATES. Indian J Gastroenterol. 2012;2(2):146-9.

81. Mohamed R, Desmond P, Suh D-J, Amarapurkar D, Gane E, Guangbi Y, et al. Practical difficulties in the management of hepatitis $B$ in the Asia-Pacific region. J Gastroenterol Hepatol. 2004;19(9):958-69.

82. Hipgrave DB, Van NT, Vu MH, Hoang TL, Do TD, Tran NT, et al. Hepatitis B infection in rural Vietnam and the implications for a national program of infant immunization. AmJTrop Med Hyg. 2003;69(3):288-94.

83. Ding CM, Sung JJY, Chan HLY, Luan J. Viral mutant discovery in hepatitis B virus quasi-species in patients undergoing long-term lamivudine treatment. Hong Kong Med J. 2015;21(Suppl 4):31-4.

84. Yin F, Wu Z, Fang W, Wu C, Rayner S, Han M, et al. Resistant mutations and quasispecies complexity of hepatitis B virus during telbivudine treatment. J Gen Virol. 2015;96(11):3302-12.

85. Younossi ZM, Tanaka A, Eguchi Y, Lim YS, Yu ML, Kawada N, et al. The impact of hepatitis $C$ virus outside the liver: Evidence from Asia. Liver Int. 2016:37(2):159-172.

\section{Submit your next manuscript to BioMed Central and we will help you at every step:}

- We accept pre-submission inquiries

- Our selector tool helps you to find the most relevant journal

- We provide round the clock customer support

- Convenient online submission

- Thorough peer review

- Inclusion in PubMed and all major indexing services

- Maximum visibility for your research

Submit your manuscript at www.biomedcentral.com/submit
) Biomed Central 